UDK: $351.746 .1(497.6)$ "1949“" Izvorni znanstveni članak

Primljen 12. IV. 2019.

VJEKoslav ČAmber

Posušje

vcamber@gmail.com

\title{
UHIĆENJA INFORMBIROOVACA U POJEDINIM SREZOVIMA ZAPADNE BOSNE U JESEN 1949. GODINE
}

\section{Sažetak}

$\mathrm{Na}$ osnovi arhivskih dokumenata iz fonda CK KP BiH, dostupnih u Arhivu Bosne i Hercegovine, i dokumenta dijelom naslovljena Knjiga sa spiskom i osnovnim podacima za sve kažnjenike DKR i osudenike po IB$u$, dostupna u Hrvatskome državnom arhivu u Zagrebu, autor prikazuje progone informbiroovaca u srezovima Glamoč, Mrkonjić Grad, Jajce, Drvar, Bosanski Petrovac i Ključ te u gospodarskim i prometnim opunomoćstvima (prometno u Jajcu i Banjoj Luci, gospodarsko u Drvaru i Elektrobosna i Energija u Jajcu). Osnova rada jest većim dijelom izvještaj s terenskoga rada djelatnika UDBA-e, koji je obavljen u jesen 1949. na prostoru navedenih srezova, a nalazi se $u$ Arhivu Bosne i Hercegovine $u$ fondu Centralnoga komiteta $\mathrm{BiH}$, u kutiji 22, pod brojem 15. Osim toga, korišteni su i izvještaji Oblasnoga komiteta Banja Luka o kažnjenima zbog Informbiroa, također dostupni u Arhivu Bosne i Hercegovine. Zbog činjenice da navedeni dokumenti iz Arhiva Bosne i Hercegovine ne sadrže daljnje informacije o sudbinama uhićenih pod optužbom da su pristaše Staljina (informbiroovci), autor za većinu njih odgovor pronalazi u gore navedenome dokumentu iz Hrvatskoga državnog arhiva $\mathrm{u}$ Zagrebu, koji je zapravo popis kažnjenika na Golome otoku.

Ključne riječi: informbiroovci; UDBA; uhićeni; Goli otok; sreski komiteti; partijska komisija 


\section{Uvod}

Objava Rezolucije Informbiroa 28. lipnja 1948., u kojoj je jugoslavenski komunistički režim optužen za „odstupanje od marksizma-lenjinizma pri provođenju unutarnje i vanjske politike“, izazvala je šok i nevjericu u međunarodnim krugovima, ali i još više u tadašnjoj komunističkoj Jugoslaviji, osobito u partijskim strukturama KPJ na svim razinama. Zbunjenosti partijskoga članstva dodatno je doprinosila i dvostruka politika koju je nakon toga provodio jugoslavenski režim, s jedne strane kroz političke reforme u zemlji i vanjsku politiku uporno se dodvoravajući Staljinu, dok se s druge strane vrlo brzo nakon izlaska Rezolucije započelo sa žestokim progonima dijela članstva koje je smatralo da je Staljin u pravu. Kada su u pitanju članstvo i dužnosnici KPJ na prostoru Bosne i Hercegovine, dodatnu pomutnju među njima izazivala je i činjenica da se u početku većina članova Pokrajinskoga komiteta za Bosnu i Hercegovinu opredijelila za navode iz Rezolucije, odnosno smatrali su da je Tito pogriješio i da se treba pokoriti Staljinu kao neospornome komunističkom autoritetu u Europi i svijetu. Nakon Titova poziva u Beograd svi članovi Pokrajinskoga komiteta promijenili su stav, odnosno popustili su pred Titovim „uvjeravanjem“ i izvukli su se nekažnjeno, za razliku od niže rangiranih ministara $\mathrm{u}$ Vladi $\mathrm{BiH}$, pomoćnika ministara $\mathrm{i}$ drugih dužnosnika u većini državnih institucija. Osim toga, "pokajnici“ koji su u početku istaknuli otvorenu podršku Staljinu, osim što nisu zaštitili one na koje su prenijeli takve stavove (ministri u Vladi i ostali dužnosnici), prometnuli su se među glavne progonitelje informbiroovaca na prostoru Bosne i Hercegovine. Tako su se već od kolovoza 1948. uz isključenja iz KPJ događala i uhićenja pojedinaca koji su ustrajali u podršci navodima iz Rezolucije, odnosno nisu popustili „uvjeravanjima“ koja su provodile partijske komisije pa su propuštali „priliku da se poprave“, kako se navodi u partijskim dokumentima o isključenima i uhićenima zbog Informbiroa. Uhićenja informbiroovaca postajala su masovnija početkom 1949. godine, odnosno postupci režima prema pristašama Rezolucije razvijali su se u skladu sa smjerom politike CK KPJ, pa su posebne kaznionice za informbiroovce (Goli otok i druge) stvarane tek kada je 
Tito shvatio da se pomirenje sa Staljinom ipak ne će dogoditi (proljeće 1949.). S druge strane, i aktivnost informbiroovaca potpuno je ovisila o potezima koje je povlačila Moskva, pa se s jačanjem Staljinova pritiska tijekom 1949. pojačala i njihova aktivnost, ali ipak ograničena na pojedince ili male grupe čije se djelovanje uglavnom svodilo na agitaciju na terenu među nezadovoljnim seljacima i radnicima, odnosno na onemogućavanje izvršavanja gospodarskih planova. Po tome pitanju iznimke nisu bili ni informbiroovci i njihove aktivnosti 1949. godine na prostoru Glamoča, Mrkonjić Grada, Jajca, Drvara, Bosanskoga Petrovca i Ključa.

\section{Akcija UDBA-e u srezovima Glamoč, Mrkonjić Grad, Jajce, Drvar, Bosanski Petrovac i Ključ krajem listopada i početkom studenoga 1949.}

Srezovi u zapadnoj Bosni: Glamoč, Mrkonjić Grad, Jajce, Drvar, Bosanski Petrovac i Ključ bili su u nadležnosti Oblasnoga komiteta KP BiH za Banjalučku oblast gdje je uklanjanje informbiroovaca najjači intenzitet imalo od kasnoga ljeta 1949. pa do mjeseca studenoga iste godine. Tako je na primjer od 25. kolovoza do 25. rujna, pod optužbom da su informbiroovci, iz partije isključeno i uhićeno 38 članova KPJ među kojima su većinom bili siromašni seljaci. ${ }^{1}$ Međutim, društveni status kažnjenih ne znači kako među njima nije bilo stvarnih informbiroovaca jer su i u društvenoj strukturi ukupnoga članstva KPJ na prostoru $\mathrm{BiH}$ 1948. godine seljaci činili 51,37 \% članstva, a 1949. 40,90 \%. ${ }^{2} \mathrm{O}$ društvenoj strukturi KPJ na prostoru $\mathrm{BiH}$ govori i mnogo partijskih dokumenata, pa je u jednome navedeno: „Naši su komunisti u najvećem broju polupismeni seljaci koji čine i jezgro većine sreskih i drugih nižih rukovodstava"3, slično kao i u Izvještaju o organizacionim pitanjima Pokrajinskoga

Usp. Arhiv Bosne i Hercegovine (dalje: A BiH), Centralni komitet Bosne i HerceGOvine (dalje: CK BIH, Izvještaj Oblasnog komiteta KP BiH za Banjalučku oblast od 3. 10. 1949., kut. 22, br. 4, tabelarni prilog.

2 Usp. Vera Katz, Društveni i ekonomski razvoj Bosne i Hercegovine 1945.-1963., Institut za istoriju, Sarajevo, 2011., str. 187-188.

3 A BiH, Pokrajinski Komitet Komunističke partije Jugoslavije za Bosnu i HerceGOvinU (dalje: PK KPJ BIH), dokument od 2. kolovoza 1945., kut. 84/1945., br. 47/45., str. 1. 
komiteta KPJ za BiH od 26. prosinca 1945. gdje se kritički navodi: „Karakteristika naše bosanskohercegovačke partijske organizacije jeste da je njen sastav seljački...“4. Takva „komunistička elita“ upravljala je svim strukturama države i društva, a od gore navedenih 38 kažnjenih informbiroovaca 11 ih je bilo na važnim partijskim funkcijama, čak 24 na državnim funkcijama, a 4 na funkcijama masovnih organizacija (s tim da su se kod pojedinaca funkcije preklapale, odnosno bili su na više dužnosti istovremeno, što znači kako su bili istaknuti „partijski kadrovi“). ${ }^{5}$

Dokument koji nam je osnova za pisanje ovoga rada odnosi se upravo na kažnjavanje informbiroovaca u navedenim srezovima $u$ isto vrijeme (kraj listopada i početak studenoga 1949.). Nalazi se u Arhivu Bosne i Hercegovine $\mathrm{u}$ fondu Centralnoga komiteta $\mathrm{BiH}$, u kutiji 22, pod brojem 15. Iako nema zaglavlja dokumenta, gdje je trebala biti informacija o naslovu i nadnevku, autoru Izvještaja i adresi na koju je upućen, na početku se navodi da su agenti UDBA-e na ovome prostoru bili od 26. listopada do 4. „ovog mjeseca“. Usporedbom imena i prezimena kažnjenih informbiroovaca iz drugih dostupnih izvještaja, koji se odnose na kažnjene informbiroovce u Banjalučkoj oblasti, jasno nam je da je 4 . „ovog mjeseca“ zapravo 4. prosinca 1949. Dakle, autor Izvještaja, dužnosnik UDBA-e, ostaje nepoznat, ali je navedeno da se radilo o grupi u kojoj je bilo pet oficira UDBA-e, dva iz Uprave ${ }^{6}$ (kapetan Gavrilović i Grubić) i tri iz oblasti ${ }^{7}$ (major Garača i kapetani Šobot i Miljević). Grupa je od 26. listopada do 4. prosinca izvršila obilaženje sreskih opunomoćstava: Glamoč, Mrkonjić Grad, Ključ, Bosanski Petrovac, Drvar, Jajce te gospodarska i prometna opunomoćstva: prometna u Jajcu i Banjoj Luci, gospodarska u Drvaru te Elektrobosna i Energija u Jajcu. U ovoj „akciji“ UDBA-e uhićeno je 17 informbiroovaca (a ne „desetak“ kako se navodi u Izvještaju) koji su bili na različitim dužnostima u srezovima i

4 A BIH, PK KPJ BIH, kut. 84/45., br. 32/45., str. 2.

5 Usp. A BIH, CK BIH, Izvještaj Oblasnog komiteta KP BiH za Banjalučku oblast od 3. 10. 1949., kut. 22, br. 4, str. 1. Akcije UDBA-e otežavala je i činjenica da je među informbiroovcima koje je trebalo uhititi bilo i troje suradnika UDBA-e (Đuro Knežević, Veljko Stanarević, Nikola Ivetić).

6 Uprava UDBA-e za BiH u Sarajevu.

7 Uprava UDBA-e za Banjalučku oblast. 
gospodarskim društvima, a osim uhićenih - još je isključeno i 26 članova KPJ zbog „bezobraznog neprijateljskog djelovanja“ kao i zbog sumnje kako bi mogli prebjeći preko granice u neku od informbiroovskih zemalja. ${ }^{8}$ Osim toga, po Izvještaju i preporukama navedenih agenata UDBA-e kasnije su, odnosno tijekom 1950. i 1951. godine, uhićena još četvorica informbiroovaca. ${ }^{9}$

\section{Uhićenja i kažnjavanja informbiroovaca u Glamoču}

Novija istraživanja uzroka i posljedica sukoba Tita i Staljina, nastala neposredno pred raspad i nakon raspada Jugoslavije te u novije vrijeme, jasno pokazuju kako opredijeljenost za Staljina i djelovanje informbiroovaca ipak nije imalo isključivo ideološku pozadinu, odnosno uglavnom se radilo o različitim vrstama političkoga nezadovoljstva, a pristajanje uz Rezoluciju omogućilo im je upravo izjašnjavanje toga nezadovoljstva. ${ }^{10}$ Na primjeru Bosne i Hercegovine isto se nesporno događalo, a u puno slučajeva presudan čimbenik kažnjavanja pojedinaca bile su osobne netrpeljivosti, osobni probitak ili položaji do kojih se željelo doći uklanjanjem onih koji su smetali i slično. Analizom ovoga Izvještaja UDBA-e vidimo kako uopće nije bilo opipljivih dokaza informbiroovskoga djelovanja kod većine kažnjenih pojedinaca ni priznanja optuženih, odnosno uglavnom se radilo o optužbama osoba koje je UDBA „pritisnula“ i zatvorila kako bi došla do informacija o „neprijateljskom informbiroovskom djelovanju“.

Izvještaj za srez Glamoč počinje tvrdnjom o „lošem stanju“ u srezu i Sreskome komitetu zbog čega su kao glavni krivci navedeni ranije

Usp. A BIH, CK BIH, kut. 22, br. 15, str. 1-20.

9 Usp. A BIH, CK BIH, kut. 22, br. 1, 2, 3, 4, 6, 71; A BIH, CK BIH, Izvještaj Oblasnog komiteta KP BiH za Banjalučku oblast iz studenog 1949., kut. 22, b. br.; A BIH, CK BıH, kut. 43, 52, 556, 568, 569/1950., br. 72, 73, 74, 75, 76, 77, 78, 79, 81, 82, 118. ABiH, CK BiH, Izvještaj Kontrolne komisije KP BiH, od 26. 5. 1951., Izdvojena građa u vezi IB-a, kut. 72-77, br. 6/51., A $\mathrm{BiH}, \mathrm{CK} \mathrm{BiH}$, kut. 82, br. 614/52, 466/52, 1328/52, 632/52, 1367/52, 519/52.

10 Usp. Ivo Banac, Sa Staljinom protiv Tita, Globus, Zagreb, 1990., str. 210; Martin Previšıć, „Informbiro križevačkog kotara od 1948. do 1958. godine“, Cris: časopis Povijesnog društva Križevci, Križevci, br. 11, 2009., str. 104-115; Dragan Marković, Josip Broz i Goli Otok, Beseda, Beograd, 1990., str. 14. 
uhićeni Marko Bjekić i Špiro Malešević. ${ }^{11}$ Njih su dvojica označeni kao krivci potpunoga izostanka „raskrinkavanja klevetničke kampanje Informbiroa“ i neizvršavanja privrednih zadataka. Dalje u tekstu UDBA razotkriva kompletnu liniju djelovanja informbiroovaca u ovome srezu od izlaska Rezolucije do nastanka Izvještaja. Prema tome pokretač i organizator djelovanja informbiroovaca bio je Miloš Vranješ ${ }^{12}$ koji je upute o načinu djelovanja iz Sarajeva prenio Marku Bjekiću, a nakon što je Bjekić uhićen, akcijama informbiroovaca rukovodili su Luka Ninković i Dimitrije Ninković. ${ }^{13}$ Ninkovići su dalje utjecali na ostale dužnosnike na rukovodećim pozicijama u sreskim ustanovama, koji su ometali stvaranje radnih zadruga, otkup vune, prijevoz sijena, mobilizaciju radne snage i potpuno zanemarili partijske direktive o „raskrinkavanju“ informbiroovaca, a $\mathrm{u}$ javnim nastupima i govorima, pa i u razgovorima $\mathrm{s}$

${ }_{11}$ Usp. A BIH, CK BIH, kut. 22, br. 15, str. 1. Marko Bjekić bio je na dužnostima organizacijskoga sekretara Sreskoga komiteta Glamoč i član plenuma Industrijskoga komiteta Drvar (Srbin po nacionalnosti, a član KPJ od 1942.), dok je Špiro Malešević bio član biroa Sreskoga komiteta Glamoč (Srbin po nacionalnosti, a član KPJ od 1944.). Njih dvojica uhićeni su krajem rujna (Bjekić), odnosno početkom listopada (Malešević) 1949. god. Obojica su bili zatočeni na Golome otoku, a oslobođeni su 28. prosinca 1951. Usp. A BIH, CK BIH, Izvještaj Oblasnog komiteta KP BiH za Banjalučku oblast iz studenog 1949., kut. 22, b. br., tabelarni prikaz; HrVATSKi dRžAVni arhiv, Zagreb (dalje: HDA), RepubličKi SEKRETARIjAT unutrašnjih poslova SocijalističKe Republike Hrvatske, Služba Sigurnosti InFORMBIRO (dalje: RSUP SRH SDS, INFORMBIRO), Knjiga sa spiskom i osnovnim podacima za sve kažnjenike DKR $i$ osuđenike po IB-u, ARHIVsKa JEDINICA (dalje: AJ) o11.10/1, G-M, str. 73, A-F, str. 21.

12 Miloš Vranješ u Sarajevu je bio na dužnosti načelnika odjeljenja PAZ-a u MUP-u BiH (Srbin po nacionalnosti, po društvenome statusu intelektualac, član KPJ od 1942.). Prema Izvještaju Oblasnoga povjerenstva KP BiH za Sarajevsku oblast uhićen je kao informbiroovac u rujnu 1949. u Sarajevu. Međutim, na popisu kažnjenika na Golome otoku navedeno je kako je uhićen 3. listopada 1949., a oslobođen je 26. rujna 1950. Usp. A BIH, CK BIH, Izvještaj Oblasnog povjerenstva KP BiH za Sarajevsku oblast od 4. 10. 1949., Spisak isključenih $i$ uhapšenih bivših članova KP BiH Sarajevo u vezi rezolucije Informbiroa, kut. 22, br. 32, str. 1-3; HDA, RSUP SRH SDS, INFORMBIRo, Knjiga sa spiskom..., N-Z, str. 109.

${ }_{13}$ Luka Ninković bio je na dužnosti sekretara Sreskoga komiteta Glamoč (Srbin po nacionalnosti, po društvenome statusu seljak, član KPJ od 1942.), uhićen je kao informbiroovac tijekom prosinca 1949. Dimitrije Ninković bio je na dužnosti šefa unutrašnjega odsjeka i član biroa Sreskoga komiteta (Srbin po nacionalnosti, po društvenome statusu seljak, član KPJ od 1942.), također je kao informbiroovac uhićen tijekom prosinca 1949. Usp. A BIH, CK BIH, Izvještaj Oblasnog komiteta za Banjalučku oblast od 31. 12. 1949., kut. 22, br. 71, tabelarni prikaz. 
pojedincima, nisu govorili protiv politike Informbiroa. ${ }^{14}$ Dakle, informbiroovci su u ovome srezu bili pozicionirani redom na visokim partijskim dužnostima, a imali su izravnu vezu i s dobro pozicioniranim Milošem Vranješom u Sarajevu, odnosno u republičkome MUP-u. Ovakvu povezanost, kada je u pitanju djelovanje informbiroovaca na prostoru Bosne i Hercegovine, nismo pronašli samo u ovome dokumentu. Slično se ponavlja i u mnogim izvještajima iz drugih oblasti (Sarajevska, Mostarska, Tuzlanska). Kada je u pitanju Banjalučka oblast, ovakva koordinacija aktivnosti informbiroovaca na terenu, rukovođena osobama koje su bile na visokim pozicijama u Sarajevu, zabilježena je i u Izvještaju koji govori o razbijanju informbiroovskih grupa tijekom srpnja 1949. u Jajcu, Banjoj Luci i Bosanskoj Dubici. ${ }^{15}$ Djelovanju informbiroovaca na terenu svakako je od pomoći bila i represija koju je režim provodio nad seljacima, odnosno prisilno stvaranje radnih zadruga i cijene otkupa poljoprivrednih proizvoda koje su zapravo bile čista pljačka seljaka kao i prisiljavanje seljaka na sudjelovanje u radnim akcijama u vrijeme kada su bili najpotrebniji na svojim imanjima. Tako da je u slučaju Glamoča u vrijeme nastanka Izvještaja (studeni 1949.) postojalo samo šest radnih zadruga u čitavome srezu, a znakovito je da u rodnome mjestu sekretara Sreskoga komiteta nije bila ni jedna. No, kada je u pitanju mobilizacija radne snage po akcijama koje je vodio Oblasni komitet Banja Luka, i tu je vlast doživjela potpuni neuspjeh jer je samo s prostora sreza Glamoč

14 Usp. A BIH, CK BIH, kut. 22, br. 15, str. 1. U prvoj fazi sukoba sa Staljinom (lipanj 1948. siječanj 1949.) Tito se nadao izmirenju sa sovjetskim vođom, pa su i sve reforme koje je režim provodio nakon V. kongresa KPJ bile usmjerene u tome smjeru, odnosno dodvoravanju sovjetima. U tome je cilju među prvim „reformama“ bila transformacija poljoprivrede po staljinističkome modelu. Kasnije kada je sovjetska blokada, uz druge čimbenike (suša, loše gospodarenje i slično), prouzročila nestašicu osnovnih životnih namirnica, kontrola poljoprivrednih dobara i proizvoda bila je jedan od jamaca opstanka jugoslavenskoga komunističkog režima (hrana za vojsku i represivne organe države), a svi koji su iz različitih razloga ustajali zbog takve politike - proglašavani su neprijateljima. Ako su bili članovi KPJ, kažnjavani su kao informbiroovci, a u suprotnome kao „klasni neprijatelji“. O učincima Rezolucije Informbiroa i Staljinove blokade na jugoslavensko gospodarstvo više u: Jozo TOMASEVICH, „Immediate effects of the Cominform Resolution on the Yugoslav economy“, Wayne S. Vucinich (ur.), At the Brink of War and Peace: The Tito - Stalin Split in a Historic Perspective, Brooklyn College Press, Brooklyn, 1982., str. 122.

15 Usp. A BıH, CK BIH, Izvještaj Oblasnog komiteta KP BiH za Banjalučku oblast od 5. 8. 1949., kut. 22, b. br., str. 1. 
oko 300 osoba otišlo raditi kao berači kukuruza u Slavoniju, unatoč izričitoj zabrani Oblasnoga komiteta. ${ }^{16}$

Do dolaska grupe UDBA-e, koja je radila ovaj Izvještaj, partijski dužnosnici koji su podržavali Informbiro bili su potpuno ovladali Sreskim komitetom u Glamoču. I to na način da su sastav Komiteta tijekom kolovoza 1949. predložili Marko Bjekić i Luka Ninković s ljudima koji su im odgovarali i slijedili njihove stavove, a Miloš Vranješ im je u Sarajevu pomogao da takav sastav potvrdi CK BiH. Tako da do dolaska djelatnika UDBA-e, koji su autori ovoga Izvještaja, ni jedan član KPJ u srezu Glamoč nije kažnjen kao informbiroovac. ${ }^{17}$ Ideološka pozadina djelovanja glavnih informbiroovaca vidi se u stavovima Luke Ninkovića koji je u različitim prilikama sugovornicima obrazlagao uzroke sukoba sa Staljinom. Po njemu je glavni krivac bio Tito, odnosno njegova "gramzivost" po pitanju želja i planova vezanih za dominaciju Balkanom i Balkanskom Federacijom, o čemu se bez Staljinova znanja i dogovarao s Dimitrovim. ${ }^{18}$ Nakon uhićenja Marka Bjekića, a strahujući od UDBA-e, u svojem je djelovanju postao konspirativniji i oprezniji pokušavajući pokazati kako on zapravo nije na „liniji IB-a“. Međutim, kada su istražitelji UDBA-e donijeli odluku o njegovu uhićenju, svaka izgovorena riječ, pa čak i njegova dnevna rutina (vrijeme dolaska i odlaska iz prostorija komiteta), označeni su kao „neprijateljska djelatnost“. Pred partijskom komisijom i agentima UDBA-e odbijao je priznati bilo kakvu povezanost s informbiroovcima, a agenti UDBA-e procijenili su da ga je potrebno odmah uhititi jer su bili svjesni njegova utjecaja u Sreskome komitetu, tako da bi eventualno „raskrinkavanje“ pred članovima Komiteta vjerojatno bilo bezuspješno. ${ }^{19} \mathrm{Na}$ kraju se to i dogodilo, pa se njegovo ime nalazi na popisu uhićenih tijekom prosinca $1949 .{ }^{20}$ Međutim, na popisu kažnjenika na Golome otoku navedeno je kako je uhićen tek 22. veljače

\footnotetext{
Usp. A BIH, CK BIH, kut. 22, br. 15, str. 2.

Usp. A BiH, CK BiH, kut. 22, br. 15, str. 2.

Usp. A BIH, CK BIH, kut. 22, br. 15, str. 2.

Usp. A BIH, CK BIH, kut. 22, br. 15, str. 3 .

${ }_{20}$ Usp. A BıH, CK BıH, Izvještaj Oblasnog komiteta za Banjalučku oblast od 31. 12. 1949., kut. 22, br. 71, str. 1-2.
} 
1950., dok je pušten 10. ožujka 1952. ${ }^{21}$ Slične stavove o uzrocima sukoba sa Staljinom imao je i Dimitrije Ninković koji se, osim toga, otvoreno suprotstavljao mjerama koje je režim provodio nad seljacima..$^{22}$ I u njegovu slučaju agenti UDBA-e u prvome trenutku nisu izvršili uhićenje, odnosno samo su istaknuli u dopisu kako je to potrebno učiniti, pa se i njegovo ime navodi među uhićenima u Izvještaju od 31. prosinca 1949. ${ }^{23}$ Na popisu zatočenika na Golome otoku navedeno je kako je uhićen 16. prosinca 1949., a na slobodu je pušten 28. prosinca $1951 .{ }^{24}$

Na ovome „pohodu“ u srezu Glamoč agenti su UDBA-e, kako su istaknuli, odmah uhitili jedino Luku Kozomara (Srbin, seljak, član KPJ od 1943.), koji je bio na dužnosti predsjednika Mjesnoga narodnog odbora Glamoč, zato što nije želio pustiti kćer u radnu brigadu na izgradnji autoputa. Osim toga, imao je "loše rezultate“ kao povjerenik za poljoprivredu u Sreskome narodnom odboru, a na sastancima na kojima se raspravljalo o Rezoluciji smatrao je da su predstavnici CK KPJ trebali ići na zasjedanje u Bukurešt. ${ }^{25}$ I njegovo je ime navedeno u Izvještaju o uhićenima zbog Informbiroa u Banjalučkoj oblasti od 31. prosinca 1949., ${ }^{26}$ a na popisu zatočenika na Golome otoku kao nadnevak njegova uhićenja naveden je 3. prosinca 1949., dok je s Gologa otoka pušten 2. kolovoza $1951 .{ }^{27}$

Osim navedenih osoba, agenti UDBA-e pred partijsku komisiju izveli su ili su planirali izvesti još pet visokopozicioniranih dužnosnika u Sreskome narodnom odboru, seoskim radnim zadrugama ili u mjesnim narodnim odborima. Tako su saslušani Marko Radoje (knjigovođa

${ }_{21}$ Usp. HDA, RSUP SRH SDS, Informbiro, Knjiga sa spiskom..., N-Z, str. 7.

22 Usp. A BIH, CK BIH, kut. 22, br. 15, str. 3.

${ }_{23}$ Usp. A BIH, CK BIH, Izvještaj Oblasnog komiteta za Banjalučku oblast od 31. 12. 1949., kut. 22, br. 71, str. 1-2.

${ }_{24}$ Usp. HDA, RSUP SRH SDS, Informbiro, Knjiga sa spiskom..., N-Z, str. 7.

25 Usp. A BIH, CK BIH, kut. 22, br. 15, str. 3.

26 Usp. A BIH, CK BIH, Izvještaj Oblasnog komiteta za Banjalučku oblast od 31. 12. 1949., kut. 22, br. 71, str. 1-2.

27 Usp. HDA, RSUP SRH SDS, Informbiro, Knjiga sa spiskom..., G-M, str. 54. 
Zadružnoga saveza), ${ }^{28}$ Rade Ćulum (matičar u MNO-u u Rorama), ${ }^{29}$ Jakišić Ilija (član Upravnoga odbora SRZ-a u Starome selu), ${ }^{30}$ Đurad Bojinović (povjerenik za financije u SNO-u Glamoč i poslanik u Saveznoj skupštini), ${ }^{31}$ dok je za Mirka Vranješa ${ }^{32}$ (nećak Miloša Vranješa), referenta Unutarnjega odsjeka u SNO-u Glamoč, najavljeno izvođenje pred partijsku komisiju jer se tada nalazio na dvomjesečnoj vojnoj vježbi. ${ }^{33}$ Od navedenih osoba dužnosnici UDBA-e najduže su obrazloženje napisali za Đurada Bojinovića koji je već ranije kažnjavan „strogim partijskim ukorom“ zbog suprotstavljanja politici prema seljacima („otvoreno je branio kulake“) kao i zbog napada na sudce koji su procesuirali „neposlušne seljake“. Također je otvoreno branio i Žujevića koji mu je bio veći autoritet nego Tito, a po Izvještaju se bavio i sabotažama (trovanje vode na pojilištu, uništavanje otkupljenoga sijena od seljaka i sl.). ${ }^{34}$

${ }_{28}$ Marko Radoje ne spominje se ni u jednome od izvještaja isključenih i uhićenih članova KPJ zbog Informbiroa u Banjalučkoj oblasti, tako da vjerojatno nije ni kažnjavan. Usp. A BIH, CK BIH, kut. 22, br. 1, 2, 3, 4, 6, 71; A BIH, CK BIH, Izvještaj Oblasnog komiteta KP BiH za Banjalučku oblast iz studenog 1949., kut. 22, b. br.

29 Rade Ćulum, Srbin, seljak, član KPJ od 1945. god. U prosincu 1949. kažnjen je isključenjem iz KPJ. Usp. A BIH, CK BIH, Izvještaj Oblasnog komiteta za Banjalučku oblast od 31. 12. 1949., kut. 22, br. 71, tabelarni prikaz.

3o Ilija Jakišić također se ne spominje ni u jednome od izvještaja o isključenima i uhićenima zbog Informbiroa u Banjalučkoj oblasti 1948. - 1951. Usp. A BIH, CK BIH, kut. 22, br. 1, 2, 3, 4, 6, 71; ABIH, CK BIH, Izvještaj Oblasnog komiteta KP BiH za Banjalučku oblast iz studenog 1949., kut. 22, b. br.

${ }^{31}$ Đurad Bojinović, Srbin, seljak, član KPJ od 1943., uhićen je kao informbiroovac tijekom studenoga 1950. Zatvoren je na Golome otoku, a pušten 16. listopada 1952. Usp. A BIH, CK BIH, Izvještaj Oblasnog komiteta KP BiH Banja Luka, od 2. 12. 1950., Izdvojeni dokumenti vezani za IB, Oblasni komiteti Banja Luka, Sarajevo, Mostar, Tuzla, kut. 43, 52, 556, 568, 569/1950., br. 82, tabelarni pregled; HDA, RSUP SRH SDS, Informbiro, Knjiga sa spiskom..., A-F, str. 24.

${ }^{32}$ Mirko Vranješ, Srbin, seljak, član KPJ od 1945., kažnjen je isključenjem iz KPJ u ožujku 1950. god. Usp. A BIH, CK BIH, Izvještaj Oblasnog komiteta KP BiH Banja Luka, od 4. 4. 195o., Izdvojeni dokumenti vezani za IB, Oblasni komiteti Banja Luka, Sarajevo, Mostar, Tuzla, kut. 43, 52, 556, 568, 569/1950., br. 74, tabelarni pregled.

33 Usp. A BIH, CK BIH, kut. 22, br. 15, str. 5.

34 Usp. A BIH, CK BIH, kut. 22, br. 15, str. 5. 


\section{Uhićenja i kažnjavanja informbiroovaca u Mrkonjić Gradu}

Slično kao i u slučaju Glamoča na početku dijela Izvještaja, koji se odnosi na situaciju u srezu Mrkonjić Grad po pitanju Informbiroa, tvrdi se kako rukovodeći kadrovi u srezu nisu „poduzimali sve mjere“ u „razobličavanju klevetničke kampanje Informbiroa i neprijateljske djelatnosti uhićenih informbiroovaca“. Do dolaska agenata UDBA-e, koji su sačinjavali ovaj Izvještaj, na prostoru sreza Mrkonjić Grad uhićeno je 12 informbiroovaca, od čega 8 u gradu i 4 u okolnim selima. Trojica uhićenih bili su članovi SNO-a, odnosno organizacijski sekretar Desa Travar, ${ }^{35}$ član plenuma SK Vojo (Vojislav) Travar $^{36}$ i Mehmed Halilović. ${ }^{37}$ Situacija je ipak procijenjena nešto boljom nego u Glamoču, točnije $u$ smislu „izvršenja planskih zadataka“, a nerad, toleriranje propusta, greške i druge slabosti partijskoga članstva pripisane su utjecaju „informbiroovskih elemenata". ${ }^{8}$ Uhićenima nije pomoglo ni što su sami agenti UDBA-e zaključili kako njihovi propusti nisu ozbiljnije prirode, odnosno uglavnom se radilo o manje bitnim komentarima, slušanju Radija Moskve i nevjerici u izvršenje planskih zadataka sreskih ustanova i poduzeća. ${ }^{39}$ Izuzetak je stavljen u slučaju Branka Danilovića, organizacijskoga

35 Desa Travar, Srbin, seljak, član KPJ od 1943. god. po Izvještaju Oblasnoga komiteta KP BiH za Banjalučku oblast. Tijekom listopada 1949. kažnjen je isključenjem iz KPJ jer je bio informbiroovac. Međutim, i njegovo ime nalazi se među zatvorenicima na Golome otoku, što znači da je uhićen nekoliko dana nakon isključenja, odnosno 30. listopada 1949., a s Gologa otoka pušten je 30. kolovoza 1951. Usp. A BIH, CK BIH, Izvještaj Oblasnog komiteta KP BiH za Banjalučku oblast iz studenog 1949., kut. 22, b. br., tablični prikaz; HDA, RSUP SRH SDS, INFORMBIRO, Knjiga sa spiskom..., N-Z, str. 96.

${ }_{36}$ Vojislav Travar, Srbin, namještenik, član KPJ od 1942. god., u vrijeme rata zatvorenik u njemačkome zatvoru. Po Izvještaju Oblasnoga komiteta KP BiH za Banjalučku oblast uhićen je kao informbiroovac tijekom listopada 1949. Prema popisu zatvorenika na Golome otoku uhićen je 9. listopada 1949., a pušten je 28. prosinca 1951. Usp. A BIH, CK BIH, Izvještaj Oblasnog komiteta KP BiH za Banjalučku oblast iz studenog 1949., kut. 22, b. br., tabelarni prikaz; HDA, RSUP SRH SDS, INFORMBIRO, Knjiga sa spiskom..., N-Z, str. 96.

37 Mehmed Halilović, musliman, radnik, član KPJ od 1947., u vrijeme rata domobran. Prema Izvještaju Oblasnoga komiteta KP BiH za Banjalučku oblast uhićen je kao informbiroovac tijekom rujna 1949. Navedeno se potvrđuje i u popisu zatočenih na Golome otoku gdje se navodi da je uhićen 15. rujna 1949., a pušten je 28. prosinca 1951.

38 Usp. A BIH, CK BIH, kut. 22, br. 15, str. 5.

39 Usp. A BIH, CK BIH, kut. 22, br. 15, str. 5. 
sekretara SK Narodne omladine i člana Biroa SK KP BiH, za kojega su preporučili uhićenje jer je bio u dobrim odnosima s Nikolom Zdrnjom na kojega se sumnjalo da je informbiroovac. Smatrali su da bi se potvrda o tome mogla dobiti ako Danilović u zatvoru oda informacije. ${ }^{40}$ Potvrda o informbiroovskome opredjeljenju Danilovića također je dobivena od zatvorenoga Mehmeda Halilovića koji je potvrdio da je Danilović upozoravao ranije uhićene informbiroovce (Dragu Srđenovića, ${ }^{41}$ Ibrahima Mehdića, ${ }^{42}$ Halila Bašića i Halila Vučkovića) da su osumnjičeni i da se čuvaju, djeluju „konspirativno i ilegalno rade“43. Danilović ipak nije tako brzo uhićen, odnosno uhićen je tek 15. veljače 1951. i zatočen na Golome otoku. Pušten je 23. travnja 1953., ${ }^{44}$ dok Zdrnjo po dokumentima u koje smo imali uvid uopće nije bio kažnjavan kao informbiroovac.

Koristeći se informacijama koje su dobili od uhićenoga Voje Travara, agenti su UDBA-e u srezu Mrkonjić Grad, osim navedenih kažnjenih informbiroovaca, pred partijsku komisiju izveli i upozorenjem ili isključenjem iz KPJ kaznili još nekoliko članova. Uglavnom se radilo o partijskim kadrovima na odgovornim pozicijama u sreskoj partijskoj strukturi. Tako je iz KPJ isključen Ljupko Milić, ${ }^{45}$ ravnatelj sreskoga građevinskog poduzeća, zbog slušanja Radija Moskve i Radija Budimpešte i zbog sumnje u mogućnost ispunjenja Petogodišnjega plana i kritike prema „otkupu“ poljoprivrednih proizvoda. ${ }^{46} \mathrm{Zbog}$ istih grijeha također

40 Usp. A BiH, CK BiH, kut. 22, br. 15, str. 5-6.

${ }_{41}$ Zatočenik na Golome otoku, uhićen 7. rujna 1949., pušten 17. ožujka 1952. Usp. HDA, RSUP SRH SDS, INFORMBIRO, Knjiga sa spiskom..., N-Z, str. 66.

42 Ibrahim Mehdić, musliman, radnik, član KPJ od 1947. god., po Izvještaju Oblasnoga komiteta KP BiH za Banjalučku oblast. Uhićen je kao informbiroovac tijekom rujna 1949. Isto se potvrđuje i u popisu zatočenika na Golome otoku gdje se navodi da je uhićen 19. rujna 1949., a pušten je 16. listopada 1952. Usp. A BIH, CK BIH, Izvještaj Oblasnog komiteta KP BiH za Banjalučku oblast od 3. 10. 1949., kut. 22, br. 4, tabelarni prilog; HDA, RSUP SRH SDS, Informbiro, Knjiga sa spiskom..., G-M, str. 85.

43 A BIH, CK BIH, kut. 22, br. 15, str. 6.

${ }_{44}$ Usp. HDA, RSUP SRH SDS, INFOrmbiro, Knjiga sa spiskom..., A-F, str. 49.

45 Ljupko Milić, Srbin, radnik, član KPJ od 1942. god. U Izvještaju Oblasnoga komiteta KP BiH za Banjalučku oblast od 31. prosinca 1949. naveden je među isključenim informbiroovcima, u kasnijim izvještajima ne spominje se među uhićenima. Usp. A BIH, CK BIH, Izvještaj Oblasnog komiteta za Banjalučku oblast od 31.12 .1949., kut. 22, br. 71, tabelarni prikaz.

46 Usp. A BIH, CK BIH, kut. 22, br. 15, str. 6. 
su isključeni Vojin Zeljković47 (predsjednik Kontrolne komisije) i Ostoja Grčić $^{48}$ (povjerenik za komunalne poslove SNO-a). Po informacijama dobivenim od Voje Travara neslaganje s planom otkupa poljoprivrednih proizvoda i uključenjem seljaka u radne brigade izrazio je i predsjednik Sreskoga suda u Mrkonjić Gradu Mirko Zdrnja koji se u to vrijeme nalazio na obuci za sudce u Sarajevu i tako izbjegao kažnjavanje. ${ }^{49}$ Agenti UDBA-e na prostoru sreza Mrkonjić Grad uhitili su samo jednoga seljaka Stojana Kežića iz sela Podorašnica, za kojega su najavili kažnjavanje po zakonu o prekršajima. Kežić je bio kandidat KPJ, a polovicom listopada u svome je selu otvoreno pozivao seljake na otpor prema „otkupu“ poljoprivrednih proizvoda hvaleći zapadne demokracije i najavljujući skoru propast „narodne vlasti“ i povratak kralja Petra..$^{50}$

\section{Situacija u Sreskome opunomoćstvu u Jajcu}

Do kraja listopada 1949. na prostoru sreza Jajce uhićeno je više informbiroovaca nego i u jednome drugom u Banjalučkoj oblasti, odnosno uhićeno ih je 62 - od čega ih je 12 bilo uposleno u poduzeću Elektrobosna. Unatoč tomu agenti UDBA-e zaključili su kako je situacija po pitanju IB-a u ovome srezu još uvijek neraščišćena, politička situacija slaba, život partijskih organizacija „neredovan“, a partijsko članstvo

47 Vojin Zeljković, Srbin, seljak, član KPJ od 1944. god., kada je iz četnika prešao u partizane. U Izvještaju Oblasnoga komiteta KP BiH za Banjalučku oblast od 31. prosinca 1949. naveden je među isključenim informbiroovcima, a u kasnijim izvještajima ne spominje se među uhićenima. Usp. A BIH, CK BIH, Izvještaj Oblasnog komiteta za Banjalučku oblast od 31.12. 1949., kut. 22, br. 71, tabelarni prikaz.

48 Ostoja Grčić, Srbin, seljak, član KPJ od 1946. god., u vrijeme rata četnik. U Izvještaju Oblasnoga komiteta KP BiH za Banjalučku oblast od 31. prosinca 1949. naveden je među isključenim informbiroovcima, u kasnijim izvještajima ne spominje se među uhićenima. Usp. A BIH, CK BIH, Izvještaj Oblasnog komiteta za Banjalučku oblast od 31. 12. 1949., kut. 22, br. 71, tabelarni prikaz.

49 Usp. A BiH, CK BiH, kut. 22, br. 15, str. 6-7.

so Usp. A BIH, CK BIH, kut. 22, br. 15, str. 5-6. Monarhističke ideje među informibiroovcima nisu bile rijetkost, mnogi pobunjenici protiv Titova režima priželjkivali su i najavljivali povratak kralja Petra, pa i u skupinama gdje su prevladavale čisto informbiroovske ideje kao što je, primjerice, bio slučaj među pobunjenim seljacima u Cazinskoj krajini početkom svibnja 1950. Usp. DARKo BeKIĆ, Jugoslavija u hladnom ratu, Globus, Zagreb, 1988., str. 126-129. 
nedisciplinirano..$^{51}$ Redovna pojava bilo je kašnjenje ili izostajanje članova KPJ na partijskim sastancima, posebno ako se radilo o sastancima na kojima je trebalo pronaći radnu snagu za javne radove. Također je i kolektivizacija poljoprivrede imala „loše“ rezultate, odnosno do tada je na prostoru sreza bilo osnovano svega šest seljačkih radnih zadruga. Sreskomu komitetu zamjereno je što uopće nisu pokretali „čišćenje informbiroovskih elemenata" iz partije kako u svezi ranije uhićenih informbiroovaca tako i kasnijih slučajeva "neprijateljskog istupanja“.52

Većina uhićenih informbiroovca bila je na istaknutijim dužnostima u Sreskome komitetu, ustanovama i na rukovodećim mjestima u poduzeću Elektrobosna. Po Izvještaju se radilo o dobro organiziranoj grupi informbiroovaca kojima su rukovodili istaknutiji informbiroovci u Sarajevu (ne navodi se koji) od kojih su i dobivali zadatke. Grupom su rukovodili Momčilo Šušnjar ${ }^{53}$ (sekretar SK-a), Franjo Rajićs4 (ravnatelj Elektrobosne), Rezak Tirićs5 i Branko Videkanić. ${ }^{56}$ Poslije uhićenja navedenih i ostalih informbiroovaca, kako je izostala bilo kakva reakcija SK-a, oni koji su ostali na slobodi i u partijskim strukturama na prostoru sreza nastavili su djelovati kao i ranije. ${ }^{57}$ Prema podatcima koji su „dobiveni“ istragama u Sarajevu i Banjoj Luci, točnije saslušanjima osuđenih na „društveno koristan rad“ (zatočeni na Golome otoku i drugdje), agenti UDBA-e su za vrijeme boravka u Jajcu uhitili Milana Malinovića, ${ }^{58}$ zemljoradnika iz Šipova, koji je već ranije isključen iz KPJ

${ }^{51}$ Usp. A BIH, CK BIH, kut. 22, br. 15, str. 7.

$52 \quad$ Usp. A BIH, CK BIH, kut. 22, br. 15, str. 7.

53 Momčilo Šušnjar uhićen je 19. lipnja 1949. Zatvoren je na Golome otoku, a pušten je 3. siječnja 1953. Usp. HDA, RSUP SRH SDS, Informbiro, Knjiga sa spiskom..., N-Z, str. 88.

54 Franjo Rajić uhićen je 16. lipnja 1949. Zatvoren je na Golome otoku, a pušten je 1. svibnja 1951. Usp. HDA, RSUP SRH SDS, INFORMBIRO, Knjiga sa spiskom..., N-Z, str. 48.

55 Rezak Tirić uhićen je 6. lipnja 1949. Zatvoren je na Golome otoku, a pušten je 28. prosinca 1951. Usp. HDA, RSUP SRH SDS, Informbiro, Knjiga sa spiskom..., N-Z, str. 91.

${ }^{56}$ Branko Videkanić uhićen je 7. kolovoza 1949. Zatvoren je na Golome otoku, a pušten je 28. prosinca 1951. Usp. HDA, RSUP SRH SDS, Informbiro, Knjiga sa spiskom..., N-Z, str. 106.

57 Usp. A BIH, CK BIH, kut. 22, br. 15, str. 8.

${ }_{58}$ Milan Malinović, Srbin, seljak, član KPJ od 1944. god. U Izvještaju Oblasnoga komiteta KP BiH za Banjalučku oblast iz studenoga 1949. navodi se među isključenim informbiroovcima, dok je na popisu kažnjenika na Golome otoku navedeno da je uhićen 13. studenoga 1949., a pušten je 1. svibnja 1951. Usp. A BIH, CK BIH, Izvještaj Oblasnog komiteta KP BiH za 
zbog slušanja Radija Moskve i ometanja izgradnje zadružnoga doma, a također je potvrđivao navode iz Rezolucije Informbiroa po pitanju narodnoga fronta i legalnosti Partije. ${ }^{59}$ Prema informacijama dobivenim od uhićenoga Salke Bibića ${ }^{60}$, zbog kritike Petogodišnjega plana i kritike nasilna stvaranja socijalizma na selu, iz Partije je isključen Kasim Burek, ${ }^{61}$ dok je učitelj Živa Rackov isključen iz KPJ jer je Titovu politiku nazvao nemarksističkom i terorom. ${ }^{62}$ Zbog slušanja vijesti Radija Moskve isključen je Avdo Kasum, povjerenik za trgovinu SNO-a, dok je Zora Anđukić, blagajnica Sreskoga zadružnog saveza, isključena iz KPJ jer je odbila uhićenu sestru nazvati „neprijateljem“.63 Zbog kritike situacije u zemlji koja je, prema njegovim riječima, prouzročena odvajanjem od SSSR-a isključen je učitelj Dragoljub Popović. ${ }^{64}$ Mustafa Žolić isključen je zbog „informbiroovskih razgovora“ s Abdulahom Mulićem, službenikom MUP-a u Sarajevu. ${ }^{65}$ Osim kažnjenih članova KPJ, agenti su UDBA-e za još nekolicinu naveli zamjerke koje bacaju sumnju na njihovu stvarnu opredijeljenost. Tako je za Jovu Milovca, organizacijskoga sekretara SK-a, navedeno da je dugo iznad kreveta držao Staljinovu sliku, dok je Đilasovu i Rankovićevu bacio „pod krevet“. Za Spirana Jokića, političkoga sekretara SK-a, istaknuli su da govori protiv Informbiroa,

Banjalučku oblast iz studenog 1949., kut. 22, b. br., tabelarni prikaz; HDA, RSUP SRH SDS, INFORMBIRO, Knjiga sa spiskom..., G-M, str. 73.

59 Usp. A BIH, CK BIH, kut. 22, br. 15, str. 8.

6o Salko Bibić uhićen je 21. srpnja 1949. Zatvoren je na Golome otoku, a pušten je 26. listopada 1950. Usp. HDA, RSUP SRH SDS, Informbiro, Knjiga sa spiskom..., A-F, str. 20.

${ }^{61}$ Kasim Burek, izjasnio se kao Srbin, član KPJ od 1948. god., za vrijeme rata služio je u mornarici Nezavisne Države Hrvatske. U Izvještaju Oblasnoga komiteta za Banjalučku oblast od 31. prosinca 1949. naveden je među isključenim informbiroovcima. Usp. ABIH, CKBIH, Izvještaj Oblasnog komiteta za Banjalučku oblast od 31. 12. 1949., kut. 22, br. 71, tabelarni prikaz.

62 Usp. A BIH, CK BIH, kut. 22, br. 15, str. 9.

${ }_{3}$ Podatke o „neprijateljskom djelovanju“ Zore Anđukić UDBA je dobila od Ivane Fašini koja je uhićena 14. rujna 1949. Zatvorena je na Golome otoku, a oslobođena je 3. kolovoza 1951. god. Usp. A BIH, CK BIH, kut. 22, br. 15, str. 9; HDA, RSUP SRH SDS, INFOrmbIro, Knjiga sa spiskom..., A-F, str. 70.

${ }^{64}$ Popović je kasnije ipak uhićen, međutim nadnevak njegova uhićenja nije naveden u dokumentima. Upisana je samo visina kazne, točnije 24 mjeseca zatvora na Golome otoku odakle je pušten nekada 1950. godine. Usp. HDA, RSUP SRH SDS, INFOrmbIro, Knjiga sa spiskom..., N-Z, str. 33 .

${ }_{65}$ Usp. A BIH, CK BIH, kut. 22, br. 15, str. 9. 
ali ne „dovoljno uvjerljivo“, a osim toga, zajedno s Milovcem kasnio je gotovo dva sata na proslavu 29. studenoga. ${ }^{66}$

U Izvještaju je posebno bila zanimljiva situacija u poduzeću Elektrobosna, gdje je u to vrijeme bilo uposleno 1080 radnika i namještenika. Prema izvještajima, osim ravnatelja Franje Rajića uhićeno je još 11 uposlenika pod optužbom da su informbiroovci. Uhićenja su izazvala veliko nezadovoljstvo u poduzeću i u samome Jajcu gdje je Rajić bio omiljen, mnogi su otvoreno izražavali nezadovoljstvo i pozivali na prosvjede protiv UDBA-e i uhićenja. Kao krivci za ovakvo stanje optuženi su rukovodeći u Sreskome komitetu koji se nisu potrudili na partijskim sastancima "raskrinkati“ Rajićevo „neprijateljsko djelovanje“ kao ni „kontrarevolucionarnu“ politiku Sovjetskoga Saveza. Daljnja kažnjavanja i uhićenja ipak su dala određeni „rezultat" u poduzeću, pa se ostvarivanje plana 70 dana prije roka i oko 80 „udarnika" među radnicima pripisalo disciplini koju su popravila upravo kažnjavanja i uhićenja informbiroovaca. ${ }^{67}$ Za vrijeme „boravka“ u poduzeću Elektrobosna djelatnici UDBA-e kaznili su dva radnika te su uhitili bravara Stojana Kovača ${ }^{68}$ jer je odbijao poslove koji ne odgovaraju njegovoj kvalifikaciji i radnomu mjestu, protivio se ranijim uhićenjima informbiroovaca, a vladajuće $u$ Partiji nazvao je ološem. Mustafa Popara, ${ }^{69}$ električar u poduzeću, kažnjen je isključenjem iz KPJ jer je tvrdio da su mu partijski sastanci dosadni, slušao je Radio Moskvu i Radio Budimpeštu, slagao se sa svime što se govorilo protiv CK KPJ-a, ali je na partijskoj komisiji priznao sve i pokajao se, pa je izbjegao uhićenje. ${ }^{70}$

66 Usp. A BIH, CK BIH, kut. 22, br. 15, str. 9-10.

${ }_{67}$ Usp. A BIH, CK BIH, kut. 22, br. 15, str. 10.

68 Stojan Kovač, Srbin, radnik, član KPJ od 1948. U Izvještaju Oblasnoga komiteta za Banjalučku oblast od 31. prosinca 1949. naveden je ipak samo među isključenima, ne i među uhićenima. Međutim, u popisu zatočenika na Golome otoku navedeno je da je uhićen 3o. studenoga 1949., a pušten je 28. prosinca 1951. Usp. A BIH, CK BIH, Izvještaj Oblasnog komiteta za Banjalučku oblast od 31. 12. 1949., kut. 22, br. 71, tabelarni prikaz; HDA, RSUP SRH SDS, INFORMBiro, Knjiga sa spiskom..., G-M, str. 52.

${ }_{69}$ Mustafa Popara, izjasnio se kao Srbin, radnik, član KPJ od 1947. god., u vrijeme rata bio je u domobranima. U Izvještaju Oblasnoga komiteta za Banjalučku oblast od 31. prosinca 1949. naveden je među isključenim informbiroovcima. Usp. A BIH, CK BIH, Izvještaj Oblasnog komiteta za Banjalučku oblast od 31.12.1949., kut. 22, br. 71, tabelarni prikaz.

70 Usp. A BIH, CK BIH, kut. 22, br. 15, str. 11. 
U Izvještaju je posebno lošom (s partijskih pozicija) opisana situacija u poduzeću Energija, kako po pitanju brige o radnicima tako i po pitanjima partijske organizacije i „raskrinkavanja“ informbiroovaca. Od 1450 stalnih uposlenika u ovome poduzeću bila su samo 74 člana KPJ. Osim toga, na radilištima ovoga poduzeća bilo je još i 800 radnika u „radnim brigadama“. Plan za 1949. godinu, do pisanja Izvještaja, u ovome je poduzeću ostvaren manji za $40 \%$ u odnosu na planirano. Nije bilo uhićenja informbiroovaca, a kako ni djelatnici UDBA-e koji su obišli poduzeće nisu imali informacija o „neprijateljskom djelovanju“, također nikoga od zaposlenih nisu kažnjavali. ${ }^{71}$

S druge strane, prilikom „obilaska“ Saobraćajnoga opunomoćstva u Jajcu uhićen je skretničar Salih Đuzićn ${ }^{72}$ koji je otvoreno nastupao kao informbiroovac istovremeno potičući i druge da slušaju i prenose vijesti Radija Moskve, onemogućuju izvršenje plana i da se na svaki mogući način bore protiv "narodne vlasti“. ${ }^{73} \mathrm{U}$ ovome poduzeću isključenjem je kažnjen Sulejman Kreso, ${ }^{74}$ željezničar, koji je po Izvještaju prikriveno „razbojnički djelovao" u partijskoj organizaciji. ${ }^{75}$

\section{Kažnjavanja i uhićenja informbiroovaca u Drvaru}

Djelatnici UDBA-e su na prostoru sreza Drvar, po vlastitoj procjeni, zatekli puno bolju situaciju po pitanju Informbiroa nego što su mislili po

71 Usp. A BIH, CK BIH, kut. 22, br. 15, str. 11-12.

72 Podatci o uhićenju Saliha Đuzića ne nalaze se ni u jednome od dostupnih izvještaja iz Banjalučke oblasti za zadnja tri mjeseca 1949. Nema ga ni u popisu kažnjenika na Golome otoku, pa je najvjerojatnije bio zatvoren u nekome drugom logoru za informbiroovce. Navedeno također svjedoči o manjkavosti mjesečnih oblasnih izvještaja o isključenim i uhićenim informbiroovcima. Usp. A BIH, CK BIH, Izvještaj Oblasnog komiteta KP BiH za Banjalučku oblast iz studenog 1949., kut. 22, b. br., tabelarni prikaz; A BıH, CK BIH, Izvještaj Oblasnog komiteta KP BiH za Banjalučku oblast od 2. 12. 1949., kut. 22, br. 6, tabelarni prikaz; A BiH, CK BıH, Izvještaj Oblasnog komiteta za Banjalučku oblast od 31. 12. 1949., kut. 22, br. 71, tabelarni prikaz.

73 Usp. A BIH, CK BIH, kut. 22, br. 15, str. 12.

${ }_{74}$ Sulejman Kreso, izjasnio se kao Srbin, član KPJ od 1945. U Izvještaju Oblasnoga komiteta za Banjalučku oblast od 31. prosinca 1949. navodi se među isključenima zbog Informbiroa. Usp. A BIH, CK BIH, Izvještaj Oblasnog komiteta za Banjalučku oblast od 31. 12. 1949., kut. 22, br. 71, tabelarni prikaz.

75 Usp. A BIH, CK BIH, kut. 22, br. 15, str. 12. 
ranije dobivenim informacijama. Postupajući po informacijama koje su dobili od ranije uhićenoga Srdića ${ }^{76}$, uhitili su Dragana Moraču, ${ }^{77}$ radnika i člana KPJ, koji je na ispitivanju priznao sve za što ga se optuživalo (širio je vijesti i stavove iz zemalja Informbiroa), a usput je dodatno optužio navedenoga Srdića kao i Milu Moraču koji je u to vrijeme bio na služenju vojnoga roka u JA. ${ }^{78} \mathrm{U}$ Industrijskome opunomoćstvu u Drvaru zatečena je situacija u kojoj je sama partijska organizacija ove ustanove kao informbiroovce kaznila dva člana, odnosno bivšega ravnatelja pilane Miloša Trikića isključenjem iz KPJ i Božu Babića (pomoćnik glavnoga ravnatelja) ukorom. Djelatnici UDBA-e koji su došli u „obilazak“ Opunomoćstva sa sobom su donijeli još dokaza o informbiroovskome djelovanju obojice, posebno Babića za kojega su najavili isključenje iz KPJ uz napomenu kako po njima obojica trebaju biti uhićeni, prvenstveno zbog jakih veza koje su imali u toj sredini, pa su i njihov utjecaj u mjesnoj zajednici smatrali štetnim za Partiju. ${ }^{79}$ Ipak ostaje nam nepoznato što se dalje događalo $\mathrm{s}$ dvojicom navedenih jer se u dostupnim dokumentima, točnije u izvještajima Oblasnoga komiteta Banja Luka i popisu zatočenika na Golome otoku ne spominju.

U još dva poduzeća, Ložionici i Željezničkoj stanici, koja su još obišli u Drvaru, gdje je radilo oko goo radnika (među kojima je bilo 180 članova KPJ), ustanovili su da je situacija „prilično dobra i zdrava“, kako po pitanju ostvarivanja plana tako i po pitanju stanja u partijskoj organizaciji.

${ }_{76}$ U Izvještaju se ne spominje ime uhićenoga, nego samo prezime Srdić, a u dostupnim izvještajima o isključenima i uhićenima zbog Informbiroa iz Banjalučke oblasti ne spominje se ni jedan Srdić. Međutim, na popisu kažnjenika na Golome otoku navode se petorica Srdića (Rade, Đorđe, Simo, Vukašin, Jovan). Dvojica su uhićeni tijekom 1949. (Rade i Simo), dok su ostala trojica uhićeni tijekom 1951. Rade Srdić uhićen je 15. lipnja 1949., a Simo Srdić 29. listopada 1949. jer su djelatnici UDBA-e, koji su boravili u Drvaru, na terenu bili od 26. listopada 1949. Možemo zaključiti kako se najvjerojatnije radilo o Radi Srdiću. Usp. A BiH, CK BIH, kut. 22, br. 1, 2, 3, 4, 6, 71; A BIH, CK BIH, Izvještaj Oblasnog komiteta KP BiH za Banjalučku oblast iz studenog 1949., kut. 22, b. br.; HDA, RSUP SRH SDS, INFOrMBIRO, Knjiga sa spiskom..., N-Z, str. 66.

77 Dragan (Drago) Morača bio je zatvorenik na Golome otoku. U popisu kažnjenika ne navodi se nadnevak njegova uhićenja, nego visina kazne (12 mjeseci) i dan kada je pušten s Gologa otoka (10. ožujka 1952.). Usp. HDA, RSUP SRH SDS, INFOrmbiro, Knjiga sa spiskom..., G-M, str. 101.

78 Usp. A BIH, CK BIH, kut. 22, br. 15, str. 12.

79 Usp. A BIH, CK BIH, kut. 22, br. 15, str. 12-13. 
Unatoč takvoj „prilično dobroj i zdravoj“ situaciji, uz odobrenje „druga ministra“ (ne navodi se kojega), zbog širenja „neprijateljske propagande" i kočenja rada sindikata uhitili su trojicu željezničara: Radu Bauka, ${ }^{80}$ Boru Prokića ${ }^{81}$ i Branka Botića. ${ }^{82}$ Djelatnici su UDBA-e, osim trojice uhićenih, isključili iz Partije još jednoga željezničara, Luku Vašalića, jer je ometao stvaranje seoskih radnih zadruga. Također je uhićen i „vanpartijac“ Fadil Bešlagić, strojovođa, za kojega su „utvrdili“ kako je radio različite vrste sabotaža kako bi onemogućio izvršenje plana transporta. ${ }^{83}$

\section{Bosanski Petrovac}

U partijskim strukturama na prostoru sreza Bosanski Petrovac zatečena je situacija u kojoj uopće nije pokretano čišćenje informbiroovaca u Sreskoj partijskoj organizaciji, odnosno sve je prebačeno na Osnovne partijske organizacije koje također nisu poduzimale ništa. Isto tako, Osnovne partijske organizacije na terenu nisu izvršavale ni druge zadatke kao što je otkup, prikupljanje poreza, mobilizacija radne snage itd. Također je i agitacija na terenu potpuno zakazala, a partijska komisija koja je trebala ispitati „nerad“ nekoliko članova SK-a mjesecima nije završavala posao, čemu je najviše doprinio bivši sekretar Dušan Vranješ. „Nepravilnosti“" su zabilježene i po pitanju otkupa poljoprivrednih proizvoda, odnosno pojedina su sela bila obvezna prikupiti više nego što su proizvodili, dok su drugima ciljano ostavljani viškovi koji su se kasnije pojavljivali u „slobodnoj prodaji“. Ovakva situacija procijenjena je kao „smišljena neprijateljska djelatnost“ za koju su najodgovornijima

8o Prema popisu zatočenika na Golome otoku Rade Bauk uhićen je 28. studenoga 1949., a pušten je 12. kolovoza 1952. Usp. HDA, RSUP SRH SDS, Informbiro, Knjiga sa spiskom..., A-F, str. 17.

${ }_{81}$ Prema popisu zatočenika na Golome otoku Božidar (Boro) Prokić uhićen je 28. studenoga 1949., a pušten je 28. prosinca 1950. HDA, RSUP SRH SDS, Informbiro, Knjiga sa spiskom..., N-Z, str. 39.

82 Prema popisu zatočenika na Golome otoku Branko Botić uhićen je 29. studenoga 1949., a pušten je 21. kolovoza 1951. Usp. HDA, RSUP SRH SDS, InFOrmbIro, Knjiga sa spiskom..., A-F, str. 28.

${ }^{83}$ Usp. A BIH, CK BIH, kut. 22, br. 15, str. 13. 
smatrani sekretar SK-a Dušan Vranješ i organizacijski sekretar SK-a Jovo Karanović. ${ }^{84}$

Do dolaska djelatnika UDBA-e na prostoru Bosanskoga Petrovca uhićena su samo tri demobilizirana oficira JA, čije je uhićenje pomoglo „otkrivanju“ još sedam osoba koje su „neprijateljski“ djelovale, a među kojima su bila dva člana KPJ i jedan kandidat KPJ, dok su ostalo bili "vanpartijci“. ${ }^{85} \mathrm{Za}$ daljnje otkrivanje informbiroovaca UDBA je koristila informacije koje je dobila od ranije uhićenoga Boška Trninića ${ }^{86}$ Kao dužnosnik u Savezu boraca Trninić je svjedočio kako je često zajedno s Dušanom Vranješom i ostalima u prostorijama Sreskoga komiteta slušao Radio Moskvu, gdje su se, između ostaloga, prisutni slagali kako u Jugoslaviji jačaju „kulački elementi“, a Vranješa je optužio kako je svjesno sabotirao prikupljanje radne snage što je tražio Oblasni komitet Banja Luka. ${ }^{87}$ Osim „dokaza“ koje im je dao Trninić, djelatnici UDBA-e Vranješu su još stavili na teret i druženje s osobama za koje se sumnjalo da su informbiroovci, a do tada su svi odreda bili provjereni partijski kadrovi i dužnosnici, posebno Jovo Karanović ${ }^{88}$ i Hasan Mujagić, ${ }^{89}$ dok

${ }_{84}$ Usp. A BIH, CK BIH, kut. 22, br. 15, str. 14.

85 Usp. A BIH, CK BIH, kut. 22, br. 15, str. 14.

86 Usp. A BIH, CK BIH, kut. 22, br. 15, str. 14. U Izvještajima Oblasnoga komiteta KPBiH za Banjalučku oblast od 31. prosinca 1949. i od 9. veljače 1950. spominju se dva Boška Trninića, prvi uhićen u prosincu 1949., a drugi u siječnju 1950. Obojica su bili srpske nacionalnosti i članovi KPJ od 1946. god., po socijalnome statusu prvi je bio seljak, a drugi radnik. Moguće je da se radi i o istoj osobi jer drugih podataka nema. Također, u popisu kažnjenika na Golome otoku navodi se samo jedan Boro (Boško) Trninić koji je uhićen 13. ožujka 1949., a pušten je već 1 . listopada 1949. Međutim, tu se očito radi o drugome čovjeku jer u izjavi, u kojoj je teretio Vranješa i ostale da slušaju radijske programe iz zemalja Informiroa, Trninić navodi da je više puta tijekom ožujka, travnja, lipnja i srpnja odlazio u zgradu SK i tamo svjedočio slušanju vijesti iz zemalja Informbiroa. Usp. A BIH, CK BIH, Izvještaj Oblasnog komiteta za Banjalučku oblast od 31. 12. 1949., kut. 22, br. 71, tabelarni prikaz; A BIH, CK BIH, Izvještaj Oblasnog komiteta KP BiH Banja Luka, od 9. 2. 195o., Izdvojeni dokumenti vezani za IB, Oblasni komiteti Banja Luka, Sarajevo, Mostar, Tuzla, kut. 43, 52, 556, 568, 569/1950., br. 73, tabelarni pregled; HDA, RSUP SRH SDS, INFOrmbiro, Knjiga sa spiskom..., N-Z, str. 97.

87 Usp. A BIH, CK BIH, kut. 22, br. 15, str. 15.

88 Jovo Karanović je prije istrage koju je provodila UDBA bio na različitim funkcijama u SK Bosanski Petrovac, a posljednja koju je obnašao bila je organizacijski sekretar SK-a. Usp. A $\mathrm{BIH}, \mathrm{CK}$ BIH, kut. 22, br. 15, str. 15-16.

${ }_{89}$ Hasan Mujagić također je bio istaknuti partijski kadar u srezu Bosanski Petrovac. Bio je povjerenik za financije SNO-a, član SK Bosanski Petrovac i zastupnik u Narodnoj skupštini NR BiH ispred sreza Bosanski Petrovac. Usp. A BiH, CK BıH, kut. 22, br. 15, str. 16. 
su samo usput navedeni Milan Karanović i Mićo Kačar, bez dodatnoga obrazloženja o funkcijama koje su obnašali.9o Optužbe koje je Trninić iznio na račun Karanovića i Mujagića uglavnom su se, kao i u slučaju Vranješa, odnosile na slušanje vijesti iz informbiroovskih zemalja, loš rad u partijskim organizacijama, financijske malverzacije i slično. Iako je u slučaju Karanovića bilo i „ideoloških rasprava“ o formi i sadržaju „narodne demokracije“, člancima Edvarda Kardelja kao i o tome je li „narodna vlast" sposobna „dotući“ ostatke kapitalizma u zemlji, jer i u toj vlasti ima ostataka „kulačkih i buržoaskih elemenata“.91

$\mathrm{Na}$ kraju je za trojicu navedenih (Dušan Vranješ, Jovo Karanović i Hasan Mujagić), kao i za dva službenika (Maho Držić i Ibro Čaušević), najavljeno kako će biti izvedeni pred partijsku komisiju..$^{92}$ Također, iako su na početku dijela Izvještaja koji se odnosi na Bosanski Petrovac naveli kako su prilikom boravka u ovome srezu uhitili jednu osobu pod optužbom da je informbiroovac, dalje se u Izvještaju to nigdje ne spominje niti se navodi identitet uhićenoga..$^{93}$

\section{Ključ}

Kao i u slučaju drugih srezova, tako se i u Ključu mjesnim rukovodećim komunistima predbacivala slaba ili nikakva angažiranost $u$ „čišćenju“ vlastitih redova od Informbiroovaca koje je UDBA „pronalazila“ u svim strukturama Partije, a posebno u SNO-u i SK-u od kojih se najviše očekivala predana „borba“ protiv „klevetničke kampanje“ IB-a. Osim sreskih partijskih struktura također se dužnosnicima i agentima UDBA-e na terenu zamjerala loša učinkovitost, tako da je do njihova dolaska na terenu ovoga sreza bilo samo deset uhićenih informbiroovaca, uglavnom niže pozicioniranih u partijskim strukturama, osim

\footnotetext{
Usp. A BIH, CK BIH, kut. 22, br. 15, str. 15.

Usp. A BIH, CK BIH, kut. 22, br. 15, str. 16-17.

Usp. A BIH, CK BIH, kut. 22, br. 15, str. 17.

Usp. A BIH, CK BIH, kut. 22, br. 15, str. 13-17.
} 
Junuza Karadžića, ${ }^{94}$ člana SNO-a, uhićenoga u rujnu, te Beće Kulenovića, ${ }^{95}$ Bećira Filipovića ${ }^{96}$ i Nenada Vidovića ${ }^{97}$ koji su uhićeni tijekom lipnja. Navedeni su u zatvoru „otkrili“ još nekoliko dobro pozicioniranih osoba u partijskim strukturama u Ključu koje su im bile bliske. Po tim „dokazima“ Sreska partijska komisija kao informbiroovce isključila je Desu Mlađenović, ${ }^{98}$ Đoku Markovića, ${ }^{99}$ Branka Petrovića, ${ }^{100}$ Bogdana Banjca ${ }^{101}$ i Miška Dakića. ${ }^{102}$ Međutim, „neprijateljsko informbiroovsko djelovanje“ isključenih članova KPJ nastavili su kažnjavati i agenti

94 Junuz Karadžić uhićen je 7. rujna 1949. Zatvoren je na Golome otoku, a pušten je 26. rujna 1950. god. Usp. HDA, RSUP SRH SDS, Informbiro, Knjiga sa spiskom..., G-M, str. 39.

95 Bećo Kolenović uhićen je 22. lipnja 1950. Zatvoren je na Golome otoku, a pušten je 31. svibnja 1952. Usp. HDA, RSUP SRH SDS, Informbiro, Knjiga sa spiskom..., G-M, str. 58.

${ }_{96}$ Bećir Filipović uhićen je 6. lipnja 1949. Zatvoren je na Golome otoku, a pušten je 5. svibnja 1951. Usp. HDA, RSUP SRH SDS, Informbiro, Knjiga sa spiskom..., A-F, str. 71.

97 Nenad Vidović uhićen je 6. lipnja 1949. Zatvoren je na Golome otoku, a pušten je 26. listopada 195o. Usp. HDA, RSUP SRH SDS, Informbiro, Knjiga sa spiskom..., N-Z, str. 106.

98 Desa Mlađenović, Srpkinja, namještenik, članica KPJ od 1945. god. Bila je članica Sreskoga komiteta i rukovoditelj komisije Agitpropa Sreskoga komiteta. U Izvještaju Oblasnoga komiteta KP BiH za Banjalučku oblast iz studenoga 1949. navedena je među isključenim članovima KPJ zbog Informbiroa tijekom listopada 1949. u Banjalučkoj oblasti. Usp. A BIH, CK BIH, Izvještaj Oblasnog komiteta KP BiH za Banjalučku oblast iz studenog 1949., kut. 22, b. br., tabelarni prikaz; A BIH, CK BIH, kut. 22, br. 15, str. 18.

99 Đoko Marković, Srbin, seljak, član KPJ od 1943. god. Bio je član komisije Agitpropa u Sreskome komitetu Ključ. U Izvještaju Oblasnoga komiteta KP BiH za Banjalučku oblast iz studenoga 1949. naveden je među isključenim članovima KPJ zbog Informbiroa tijekom listopada 1949. u Banjalučkoj oblasti. Usp. A BIH, CK BIH, Izvještaj Oblasnog komiteta KP BiH za Banjalučku oblast iz studenog 1949., kut. 22, b. br., tabelarni prikaz; A BIH, CK BIH, kut. 22, br. 15, str. 18.

100 Branko Petrović, Srbin, seljak, član KPJ od 1945. god. Bio je član Sreskoga komiteta Ključ. U Izvještaju Oblasnoga komiteta KP BiH za Banjalučku oblast iz studenoga 1949. naveden je među isključenim članovima KPJ zbog Informbiroa tijekom listopada 1949. god. u Banjalučkoj oblasti. Usp. A BIH, CK BIH, Izvještaj Oblasnog komiteta K PBiH za Banjalučku oblast iz studenog 1949., kut. 22, b. br., tabelarni prikaz; A BIH, CK BIH, kut. 22, br. 15, str. 18.

Bogdan Banjac, Srbin, seljak, član KPJ od 1947. god. Bio je povjerenik SNO-a Ključ. U Izvještaju Oblasnoga komiteta KP BiH za Banjalučku oblast iz studenoga 1949. naveden je među isključenim članovima KPJ zbog Informbiroa tijekom listopada 1949. u Banjalučkoj oblasti. Usp. A BIH, CK BIH, Izvještaj Oblasnog komiteta KP BiH za Banjalučku oblast iz studenog 1949., kut. 22, b. br., tabelarni prikaz; A BIH, CK BIH, kut. 22, br. 15, str. 18.

${ }_{102}$ Miško Dakić, Srbin, seljak, član KPJ od 1946. god. Bio je direktor trgovine u seljačkoj radnoj zadruzi. U Izvještaju Oblasnoga komiteta KP BiH za Banjalučku oblast iz studenoga 1949. naveden je među isključenim članovima KPJ zbog Informbiroa tijekom listopada 1949. u Banjalučkoj oblasti. Usp. A BıH, CK BıH, Izvještaj Oblasnog komiteta KP BiH za Banjalučku oblast iz studenog 1949., kut. 22, b. br., tabelarni prikaz; A BIH, CK BIH, kut. 22, br. 15, str. 18. 
UDBA-e nakon dolaska u Ključ donijevši sa sobom i nove „dokaze“ o navedenim i drugim informbiroovcima. Ti novi dokazi temeljili su se na „priznanju“ ili informacijama koje su u zatvoru dali Bećo Filipović, uhićen neposredno pred njihov dolazak na ovaj prostor, ${ }^{103}$ Đoko Marković i Junuz Karadžić. ${ }^{104}$ Priznajući svoje informbiroovsko opredjeljenje, Filipović je otkrio niz komunističkih dužnosnika u ovoj oblasti koji su imali slične stavove ili su podržavali njegove. Takav je bio slučaj sa Smailom Džafićem, članom SNO-a i službenikom Oblasnoga suda u Banjoj Luci koji se dalje ne spominje niti je i u jednome dostupnom dokumentu iz ove oblasti zabilježen među kažnjenima. ${ }^{105}$ Kroz Izvještaj je sasvim jasno kako je bilo različitih uzroka isključenja, za pojedince je bilo kakva riječ izgovorena na pogrešnu mjestu i u pogrešno vrijeme često bila kobna. Osobne netrpeljivosti, želja za tuđim položajem ili nečim drugim često su bile povod svjedočenju protiv osumnjičenih informbiroovaca, tako da se kod pojedinaca tek nakon isključenja javljao pravi revolt, želja za osvetom i prijetnje ubojstvom „svjedocima“. Takav je bio slučaj Bogdana Banjca kojega je na osnovi svjedočenja pojedinaca (jedan od njih je bio Čerim Palislamović) partijska komisija najprije isključila iz KPJ, da bi dolaskom djelatnika UDBA-e na prostor sreza, uz dodatne „dokaze“ dobivene od Đoke Markovića, bio uhićen. ${ }^{106}$ „Dokazi“ dobiveni od

${ }_{103}$ Bećo Filipović uhićen je 17. listopada 1949. Bio je zatvoren na Golome otoku odakle je pušten 1. svibnja 1951. U Izvještaju se navodi ime Bećir Filipović što je očito greška jer je postojao čovjek takvoga imena i prezimena, također uhićen, ali 6. lipnja 1949., znači nekoliko mjeseci ranije, a ne pred dolazak djelatnika UDBA-e u Ključ, a i u samome se Izvještaju navodi da se radi o Bećiru Filipoviću starijem. I Bećir Filipović (mlađi) također je bio zatočen na Golome otoku odakle je pušten 5. svibnja 1951. Usp. A BiH, CK BIH, kut. 22, br. 15, str. 18.; HDA, RSUP SRH SDS, INFORMBIRo, Knjiga sa spiskom..., A-F, str. 71.

${ }_{104}$ Usp. A BIH, CK BIH, kut. 22, br. 15, str. 18-19.

105 Usp. A BIH, CK BIH, kut. 22, br. 15, str. 18; A BIH, CK BIH, kut. 22, br. 1, 2, 3, 4, 6, 71; A BIH, CK BIH, Izvještaj Oblasnog komiteta KP BiH za Banjalučku oblast iz studenog 1949., kut. 22, b. br.; ABIH, CK BIH, kut. 43, 52, 556, 568, 569/1950., br. 72, 73, 74, 75, 76, 77, 78, 79, 81, 82, 118. A BiH, CK BiH, Izvještaj Kontrolne komisije KP BiH, od 26. 5. 1951., Izdvojena građa u vezi IB-a, kut. 72-77, br. 6/51., ABiH, CK BiH, kut. 82, br. 614/52, 466/52, 1328/52, 632/52, $1367 / 52,519 / 52$.

106 Bogdan Banjac, Srbin, seljak, član KPJ od 1944. god. Uhićen je 3o. studenoga 1949. Zatvoren je na Golome otoku odakle je pušten 28. prosinca 1951. Usp. A BIH, CK BIH, kut. 22, br. 15, str. 18; A BIH, CK BIH, Izvještaj Oblasnog komiteta KP BiH za Banjalučku oblast iz studenog 1949., kut. 22, b. br., tabelarni prikaz; A BıH, CK BıH, Izvještaj Oblasnog komiteta KP BiH 
uhićenoga Junuza Karadžića korišteni su u kažnjavanju Dese Malđenović koja je, između ostaloga, kritizirala uhićenja oficira UDBA-e i JA kao informbiroovaca, dok su protiv njezina muža Čede Mlađenovića, direktora ugostiteljskoga poduzeća u Ključu, korišteni dokazi dobiveni od Bećira Filipovića. Osim što je „neznalicama“ nazvao najviše kadrove "narodne vlasti“ i nije vjerovao u izgradnju socijalizma bez sovjetske pomoći, otežavajuća okolnost za Čedu Mlađenovića bila je i ta što je kao trgovac po profesiji dolazio iz bogate seljačke („kulačke“) obitelji pa je, osim kao informbiroovac, označen i kao klasni neprijatelj. ${ }^{107}$ Informacije dobivene na „saslušanju“ Đoke Markovića o „aktivnom informbiroovskom djelovanju" partizanskoga ratnog zapovjednika na ovome području, potpukovnika Mitra Kovačevića, uvjerile su djelatnike UDBA-e da je Marković agent sovjetske obavještajne službe, pa su preporučili da ga se isključi iz KPJ i uhiti. ${ }^{108}$ Osim toga, partijskoj su komisiji predati prijedlozi za isključenje još nekoliko komunista: Save Macanovića (po svjedočenju Đoke Markovića), Ađula Šehića (obućar u Ključu), Slobodana Buvača, ${ }^{109}$ Đorđa Risa (povjerenik SNO-a, po svjedočenju Đoke Markovića). ${ }^{110}$

Banja Luka, od 9. 2. 1950., Izdvojeni dokumenti vezani za IB, Oblasni komiteti Banja Luka, Sarajevo, Mostar, Tuzla, Kutije 43, 52, 556, 568, 569/1950., br. 73, tabelarni pregled; HDA, RSUP SRH SDS, INFORMBIRO, Knjiga sa spiskom..., A-F, str. 14.

107 Usp. A BIH, CK BIH, kut. 22, br. 15, str. 19.

108 Usp. A BIH, CK BIH, kut. 22, br. 15, str. 20; Mitar Kovačević (Srbin, seljak, član KPJ od 1943., poslije rata sekretar SNO-a Ključ), po ovoj je „preporuci“ kasnije i uhićen što nam potvrđuje Izvještaj Oblasnoga komiteta KP BiH Banja Luka od 1. ožujka 1950. Usp. A BIH, CK BIH, Izvještaj Oblasnog komiteta KP BiH Banja Luka, od 1. 3. 1950., Izdvojeni dokumenti vezani za IB, Oblasni komiteti Banja Luka, Sarajevo, Mostar, Tuzla, kut. 43, 52, 556, 568, 569/1950., br. 72, tabelarni pregled.

109 Slobodan Buvač, Srbin, seljak, član KPJ od 1943. Bio je službenik SNO-a koji je pred partijskom komisijom odbio prokazati Bogdana Banjca kao informbiroovca, zbog čega je isključen iz KPJ. Usp. A BIH, CK BIH, kut. 22, br. 15, str. 21; A BIH, CK BIH, Izvještaj Oblasnog komiteta KP BiH Banja Luka, od 9. 2. 1950., Izdvojeni dokumenti vezani za IB, Oblasni komiteti Banja Luka, Sarajevo, Mostar, Tuzla, kut. 43, 52, 556, 568, 569/1950., br. 73, tabelarni pregled.

${ }_{110}$ Usp. A BIH, CK BIH, kut. 22, br. 15, str. 21. 


\section{Saobraćajno opunomoćstvo Banja Luka}

Prema Izvještaju, u ovome Opunomoćstvu do listopada 1949. bilo je uhićeno 13 informbiroovaca, od čega najviše u Ložioni u Banjoj Luci gdje je od 40 članova KPJ njih 5 bilo uhićeno (4 na rukovodećim pozicijama). Većina uhićenih informbiroovcima u Ložioni bila je na rukovodećim pozicijama, odnosno šef ložione Dobrivojević, ${ }^{111}$ njegov zamjenik Jakovljević, ${ }^{112}$ partijski rukovoditelj Jelovica, ${ }^{113}$ nadzornik lokomotiva $\mathrm{Bu}$ ćma, ${ }^{114}$ dok se za petoga uhićenog, strojovođu Hadžibegovića, ${ }^{115}$ navodi da je bio „vanpartijac“, odnosno nije bio član KPJ. ${ }^{116}$ I u drugim poduzećima također su redom uhićivani rukovodeći kadrovi, tako su u Službi radničkoga snadbdijevanja uhićeni direktor Snajder, personalni referent Mile Rajinović i službenik Valentin Klečina. ${ }^{117}$ Iako u slučaju Mile Rajinovića u službenim dokumentima stoji da je izvršio samoubojstvo u

${ }_{111}$ Vjerojatno se radi o Dragutinu Dobrivojeviću koji je uhićen 28. ožujka 1949. Bio je zatvoren na Golome otoku (jedini od muškaraca s ovim prezimenom) odakle je pušten 25. rujna 1950. Usp. HDA, RSUP SRH SDS, INFORMBIRO, Knjiga sa spiskom..., A-F, str. 54.

112 U Izvještaju se ne navodi ime Jakovljevića, a na popisu kažnjenika na Golome otoku nalazi se osam zatvorenika s ovim prezimenom (Danilo, Milan, Svetislav, Panta, Stanimir, Mirko, Lidija, Jovan). Uzimajući u obzir vrijeme uhićenja, onda se može raditi o Danilu Jakovljeviću (uhićen 7. svibnja 1949., a pušten 3. prosinca 1953.) ili o Jovanu Jakovljeviću (uhićen 6. listopada 1949., a pušten 28. prosinca 1951.). Usp. HDA, RSUP SRH SDS, INFOrmbIro, Knjiga sa spiskom..., G-M, str. 23.

${ }_{113}$ Najvjerojatnije je u pitanju Rihard Jelovica, uhićen 24. listopada 1949., zatvoren na Golome otoku odakle je pušten 28. prosinca 1951. Usp. HDA, RSUP SRH SDS, InFOrmbIRO, Knjiga sa spiskom..., G-M, str. 27.

114 U pitanju je Uroš Bućma, Srbin, seljak, član KPJ od 1948., što potvrđuje i Izvještaj Oblasnog komiteta KP BiH za Banjalučku oblast iz studenoga 1949. Bućma je uhićen 24. listopada 1949., zatvoren je na Golome otoku odakle je pušten 2. kolovoza 1951. Usp. A BIH, CK BIH, Izvještaj Oblasnog komiteta KP BiH za Banjalučku oblast iz studenog 1949., kut. 22, b. br., tabelarni prikaz; HDA, RSUP SRH SDS, INFOrmbIro, Knjiga sa spiskom..., A-F, str. 32.

115 U pitanju je Ragib Hadžibegović, musliman, intelektualac, za kojega se u Izvještaju Oblasnog komiteta KP BiH za Banjalučku oblast od 2. 12. 1949. ipak navodi da je bio član KPJ od 1947. god. Usp. A BIH, CK BIH, Izvještaj Oblasnog komiteta KP BiH za Banjalučku oblast od 2. 12. 1949., kut. 22, br. 6, tabelarni prikaz.

116 Usp. A BIH, CK BIH, kut. 22, br. 15, str. 21.

117 Usp. A BIH, CK BIH, kut. 22, br. 15, str. 21; Za Snajdera nema dostupnih podataka u izvještajima Oblasnog povjerenstva Banja Luka, također nije ni na popisu kažnjenika na Golome otoku, dok je Valentin Klečina uhićen 30. svibnja 1949. Zatvoren je na Golome otoku, a pušten je 2. kolovoza 1951. Usp. HDA, RSUP SRH SDS, Informbiro, Knjiga sa spiskom..., G-M, str. 43 . 
zatvoru, a takva je istina bila plasirana i u javnost, na terenu nisu svi vjerovali u to, odnosno imali su i drugačije informacije po kojima su Rajinovića u zatvoru na smrt pretukli djelatnici UDBA-e. Priče o teroru koji je provodila UDBA kao i o mučenjima u potopljenim podrumima dolazile su i do agenata UDBA-e koji su imali široku mrežu doušnika. To se naravno nije opraštalo, pa je zbog toga najavljeno i kažnjavanje Steve Ljuboje, poslovođe u Ložioni. ${ }^{118}$ Osim uhićenih koji su u Izvještaju navedeni punim imenom i prezimenom ili samo prezimenom, do kraja listopada uhićeno je još nekoliko osoba čiji je identitet potpuno nepoznat, odnosno navedena su samo radna mjesta i poduzeće u kojem su radili. ${ }^{119}$ Unatoč brojnim uhićenima, UDBA je mjesnim partijskim organizacijama zamjerala da ne rade dovoljno na „raskrinkavanju klevetničke kampanje i uhićenih informbiroovaca“, pa su se zbog toga po njima i događala brojna negodovanja zbog uhićenja, sažalijevanja uhićenih i posljedično i nastavak „neprijateljske djelatnosti“ osoba koje su bile povezane s uhićenima. Pomaganje obitelji uhićenih novčano i materijalno UDBA je posebno rigorozno kažnjavala, kao što je bio slučaj s Gojkom Carevićem. ${ }^{120} \mathrm{~S}$ druge strane, partijskim su dužnosnicima koji su zaustavljali prikupljanje sredstava među radnim kolegama uhićenih (npr. za suprugu uhićenoga Mirka Opačića ${ }^{121}$ ), a da nisu kažnjavali pokretače i sudionike takvih akcija, također izricane partijske opomene. ${ }^{122}$

118 Usp. A BIH, CK BIH, kut. 22, br. 15, str. 23.

119 Nakon nekoliko osoba koje su navedene imenom i prezimenom autori Izvještaja kratko nastavljaju obrazloženjem da su „u Željezničkoj stanici uhićena su dva činovnika i jedan skretničar a u Prijedoru dvojica službenika“. Usp. A BIH, CK BIH, kut. 22, br. 15, str. 21.

120 Gojko Carević, Srbin, seljak, član KPJ od 1944. god. kada je iz četnika prešao u partizane. Poslije rata bio je radnik na željezničkoj stanici. Uhićen je kao informbiroovac jer je novčano pomagao (s 200 dinara) obitelj uhićenoga Mirka Opačića. Zatvoren je na Golome otoku odakle je pušten 2o. ožujka 1951. Usp. A BIH, CK BIH, kut. 22, br. 15, str. 21; A BIH, CK BIH, Izvještaj Oblasnog komiteta KP BiH Banja Luka, od 1. 3. 1950., Izdvojeni dokumenti vezani za IB, Oblasni komiteti Banja Luka, Sarajevo, Mostar, Tuzla, kut. 43, 52, 556, 568, 569/1950., br. 72, tabelarni pregled; HDA, RSUP SRH SDS, InfOrmBIRO, Knjiga sa spiskom..., A-F, str. 37 .

${ }^{121}$ Mirko Opačić, službenik Željezničke stanice, uhićen je 21. studenoga 1949. Zatvoren je na Golome otoku, a pušten je 25. veljače 1954. Usp. HDA, RSUP SRH SDS, INFOrmBIRO, Knjiga sa spiskom..., N-Z, str. 12.

${ }_{122}$ Usp. A BIH, CK BIH, kut. 22, br. 15, str. 22. 
Istina o situaciji u kojoj se našla država i režim nakon raskida sa Staljinom također je kažnjavana zatvorom, odnosno kao neprijatelje i informbiroovce kažnjavalo se sve koji su govorili o nerealnosti Petogodišnjega plana, ${ }^{123}$ teškoj ekonomskoj situaciji koja je bila sve teža pod sovjetskom blokadom ili su vlast Josipa Broza Tita ocijenili jednostavno

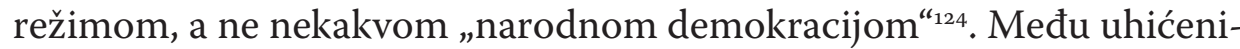
ma je bilo i onih koji su (sudeći barem po dokumentima UDBA-e) zaista bili ideološki opredijeljeni informbiroovci ili su to smatrali ispravnim. U takvu razmišljanju javno su branili Hebranga i Žujovića i smatrali ispravnom smjenu CK KPJ zbog jačanja „kulačkih elemenata“ na selu. Takve su tvrdnje u Izvještaju navedene za Ivana Peršića ${ }^{125}$ i Mitra Holoda ${ }^{126}$ koji su uhićeni nakon dolaska agenata UDBA-e u poduzeća u kojima su radili. ${ }^{127}$

Izvještaj o obilasku sreskih partijskih organizacija i partijskih organizacija u poduzećima završava preporukom za daljnja kažnjavanja i uhićenja pojedinaca za koje su imali sumnje ili „dokaze“ o informbiroovskoj opredijeljenosti, a u to su vrijeme bili odsutni. Tako se preporuča kažnjavanje Hazima Pličanića (tada pomoćnik personalnoga referenta u Željezničkoj radionici), Luke Jovića (poslovođa Ložione), Rudolfa Zigera (šef računovodstva Ložione). ${ }^{128}$

${ }_{123}$ Početkom 1951. god. javnosti je priopćeno kako je Narodna skupština FNRJ na posljednjem zasjedanju izglasala Zakon o produženju petogodišnjeg plana za jednu godinu, što je zapravo bilo svojevrsno priznanje lošega planiranja i izvršenja plana za koji je od početka bilo jasno kako je dobrim dijelom neostvariv. $\mathrm{S}$ druge strane, o onima koji su robijanjem ili gubitkom života platili kritiziranje neostvarivoga ili „neprovođenje“ planova, naravno, nije bilo ni riječi. Usp. „Povodom produženja Petogodišnjeg plana za jednu godinu“, u: Oslobođenje, br. 1307, Sarajevo, 5. 1. 1951., str. 1.

124 A BIH, CK BIH, kut. 22, br. 15, str. 22.

125 Ivan Peršić, zamjenik šefa Ložione u Banjoj Luci, uhićen je 3o. studenoga 1949. Zatvoren je na Golome otoku odakle je pušten 1. svibnja 1951. Usp. A BIH, CK BIH, kut. 22, br. 15, str. 22; HDA, RSUP SRH SDS, INFORMBiro, Knjiga sa spiskom..., N-Z, str. 24.

126 Prema popisu kažnjenika na Golome otoku Mitar Holod (jedini s ovim prezimenom), bravar u željezničkoj radionici, uhićen je 21. srpnja 1950., dakle ne u studenome, ali je najvjerojatnije u pitanju administrativna pogrješka jer je bio kažnjen s 24 mjeseca zatvora. Pušten je 31. srpnja 1950. Usp. A BIH, CK BIH, kut. 22, br. 15, str. 22; HDA, RSUP SRH SDS, INFORMBIRO, Knjiga sa spiskom..., G-M, str. 14.

127 Usp. A BIH, CK BIH, kut. 22, br. 15, str. 22.

${ }_{128}$ Usp. A BIH, CK BIH, kut. 22, br. 15, str. 23. 


\section{Zaključak}

$\mathrm{Na}$ primjeru progona, kažnjavanja i uhićenja informbiroovaca na prostoru srezova Glamoč, Mrkonjić Grad, Jajce, Drvar, Bosanski Petrovac, Ključ te u partijskim strukturama gospodarskih i prometnih opunomoćstava u zapadnoj Bosni (prometna u Jajcu i Banjoj Luci, gospodarsko u Drvaru, Elektrobosna i Energija u Jajcu) potvrđuje se čitav niz do sada postavljenih teza o uzrocima opredjeljenja jugoslavenskih komunista za Staljina u sukobu s Josipom Brozom Titom, a isto tako i uhićenja, kažnjavanja i progon informbiroovaca. Rezultat „terenskoga rada" djelatnika UDBA-e tijekom studenoga i prosinca 1949. u navedenim srezovima jest 17 uhićenih informbiroovaca i više od 20 isključenih članova KPJ, a većinu uhićenih, odnosno njih 15, pronašli smo u popisu kažnjenika na Golome otoku gdje su izdržavali kazne od jedne do četiri godine prisilnoga rada. Kada su u pitanju uzroci kažnjavanja, vidljivo je kako su različiti za svakoga pojedinca. Među njima bilo je i „stvarnih“ informbiroovaca koji su u suradnji s istomišljenicima pozicioniranim $\mathrm{u}$ republičkim institucijama pokušavali organizirano djelovati i preuzeti upravljanje partijskim strukturama na mjesnoj razini (srezovi). Zapravo je na primjeru većine kažnjenika u ovim srezovima, kao i vjerojatno u većini ostalih sredina tadašnje države, veoma teško razdijeliti „stvarne“ od „imaginarnih“ informbiroovaca. I to prvenstveno iz razloga što je uzrok kažnjavanja kod većine bio otpor „mjerama“ koje je Titov režim provodio na selu i među seljacima, odnosno „stvarni“ su informbiroovci upravo na tome pokušavali graditi svoj uspjeh i stvoriti što veći otpor prema jugoslavenskomu režimu, dok su „imaginarni“ informbiroovci otporom Titovim mjerama na selu zapravo samo štitili svoja imanja, obitelji, susjede, prijatelje i način života. Kod jednoga broja kažnjenih informbiroovaca vidljiva je ideološka komponenta na tragu kritika iz Staljinovih pisama i Rezolucije Informbiroa, kao što su zamjerke Titu zbog dogovora s Dimitrovim o stvaranju Balkanske Federacije ili podrška Hebrangu i Žujeviću. Također je među uhićenima bilo onih koji su priželjkivali propast Titova režima i povratak kralja Petra i monarhije, ali i nesretnika koji su završili na Golome otoku štiteći interese svoje djece 
(npr. odlazak kćeri u radne brigade). U dokumentu vidimo i potvrdu teze da su među uhićenima bili mnogi koji su iz različitih razloga uklonjeni kao smetnja, bilo da se radilo o ranijim razračunavanjima, osveti, želji za tuđim položajem ili slično. Takav je slučaj i trojice uhićenih željezničara iz Drvara koji su bez ikakvih istražnih radnji i dokaza uhićeni kao informbiroovci po „odobrenju druga ministra“. U njihovu slučaju nije ispoštivana ni administrativna procedura kažnjavanja informbiroovaca određena statutom KPJ. Metode istraživanja i prikupljanja dokaza koje je koristila UDBA bile su uhodane i „provjerene“, odnosno do informacija se dolazilo uhićenjima "sumnjivaca“ koje se onda „obrađivalo“ u zatvoru kako bi se izvukle informacije o ostalima. Očito je kako su pojedinci mučenjima bili prisiljeni na priznanja vlastitih „grijeha“, ali i drugih - kolega na poslu, susjeda, prijatelja, rodbine. Društvena i nacionalna pripadnost sedamnaest uhićenih (13 Srba, 3 muslimana, 1 Hrvat) također je odraz partijskih struktura na ovome prostoru gdje su na rukovodećim pozicijama i u članstvu dominirali Srbi, uglavnom seljaci i članovi KPJ od ratnih godina (1942., 1943., 1944.), među kojima je bilo partizanskih ratnih zapovjednika, ali i bivših četnika koji su u dogledno vrijeme prešli u partizane. 


\section{ARRESTS OF COMINFORM SUPPORTERS IN SEVERAL COUNTIES OF WEST BOSNIA IN THE AUTUMN OF 1949}

\section{Abstract}

On the basis of archive documents from CK KP BiH fond, available in the Archive of Bosnia and Herzegovina and a document called Book with the list and basic data for all DKR prisoners and IB convicts, available in the Croatian state archives, the author gives an overview of prosecutions of the Cominform supporters in the counties Glamoc, Mrkonjic Grad, Jajce, Drvar, Bosanski Petrovac and Kljuc as well as in the economic and traffic committees (traffic one in Jajce and Banja Luka and economic in Drvar and Elektrobosna and Energija in Jajce. The main part of the paper is the report from the field work of the UDBA employees, which was published in the autumn of 1949 in the area of the above mentioned counties. It can be found in the Archive of Bosnia and Herzegovina in the fund of Central Committee of $\mathrm{BiH}$, in the box 22 under the number 15. Besides that the author used reports of the Regional Committee Banja Luka on the people punished for Cominform. They are also available in the Archive of Bosnia and Herzegovina. Due to the fact that the mentioned documents from the Archive of Bosnia and Herzegovina do not contain further information about destines of the people arrested under the accusation that they were Stalin supporters (Cominform supporters), the author finds the answer for most of them in the above mentioned document from the Croatian state archive in Zagreb. That is in fact a list of convicts on Goli otok.

Keywords: Cominform supporters; UDBA; arrested; Goli otok; county committees; party commission 